\title{
デジタルカメラ画像を用いた淡路島・成ヶ島における 底質環境モニタリング
}

\author{
Environment monitoring on Coastal Sediment by using digital camera images \\ in Narugashima at Awaji Island
}

\author{
宇野宏司 ${ }^{1} \cdot$ 濱森 $^{\text {彩 }^{2} \cdot \text { 辻本剛三 }^{3} \cdot \text { 柿木哲哉 }}{ }^{4}$ \\ Kohji UNO, Aya HAMAMORI, Gozo TSUJIMOTO and Tetsuya KAKINOKI
}

\begin{abstract}
This paper proposes a new method of the environment monitoring on coastal sediment. To clarify the temporal-spatial variation of median grain size and effect on coastal vegetation, we applied the method for determining grain size from digital camera images of sediment proposed by Rubin to the sediment at the sandy beach in the Narugashima Island which is located at the mouth of Osaka bay, Japan. We also applied EOF (empirical function) analysis to the temporalspatial data of median grain size which was obtained by above method and extracted the principal component which rules sediment dynamics. From the results of estimation of the amount of wind-blown sand, the sediment tends to move in north- south direction in summer season and in east-west direction in winter one, respectively.
\end{abstract}

\section{1. はじめに}

成ヶ島（図-1，写真-1）は淡路島南東部に位置する砂 嘴状の島で, その形状から「淡路橋立」と言われ，瀬戸 内海国立公園の一部に指定されている。本島はハクセン シオマネキ (Uca lactea) やハマボウ (Hibiscus hamabo) といった貴重な動植物が生息するほか, アカテガニ (Chiromantes haematocheir) やアカウミガメ (Caretta caretta）の産卵地にもなっている. また, 細田（2007） は，1994年より開始した調査結果をもとに本島と淡路島 との間に位置する由良湾におけるアマモ (Zostera marina) 場の復活の経緯について検証し, 成ヶ島の豊かな植生に ついて報告している.

その一方で, 潮流により運ばれてきた浮遊ごみが大量 に押し寄せるため（宇野ら，2009）, 生態系への影響等, 砂浜環境の悪化が眯念されている. 本島東岸に拡がる自 然砂浜は海岸保全施設としての役割が期待されるが, そ の時空間的な動態については吉田ら（2002）の報告があ る程度で, 十分には把握されていない.

そこで本研究では, 底質・海浜植生分布と風の特性把 握に係る現地調査, 底質特性の時空間変動に関する統計 解析, 現地の風の出現特性を考慮した飛砂量計算を行い, 成ヶ島東岸砂浜における底質の季節変化とその要因につ いて検討した。

\begin{tabular}{|c|c|c|}
\hline $\begin{array}{l}1 \text { 正会員 } \\
2 \text { 学生会員 }\end{array}$ & 博 (工) & $\begin{array}{l}\text { 神戸市立工業高専准教授 } \\
\text { 神戸市立工業高専専攻科都市工学専攻 }\end{array}$ \\
\hline フェロー & 工博 & 神戸市立工業高専教授 \\
\hline 正会員 & 博 (工) & 神戸市立工業高専准教授 \\
\hline
\end{tabular}

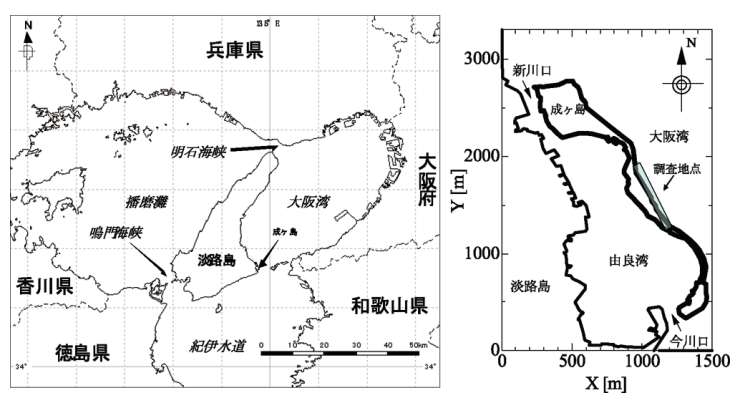

図-1 調查地点（淡路島・成ヶ島）

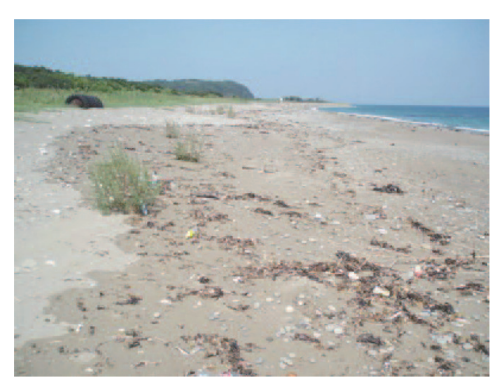

写真-1 調查地点（淡路島・成ヶ島）

\section{2. デジタル画像を利用した底質粒径の算出方法}

砂浜の底質調査, とりわけ粒度分布や平均粒径等の底 質特性の把握については, 通常, 現地で採取したものを 実験室に持ち帰り，室内でふるい試験を実施するという 手順がとられる。こうした従来の調査方法では多大な労 力と時間を要するため, 調査域を縮小したり, サンプリ ング間隔を粗にする必要があり, 海岸底質の詳細な時空 間変動を把握することが困難であった。

しかし, 近年, 光学技術の目覚しい進歩により, 市販 
表-1 撮影条件

\begin{tabular}{l|l}
\hline \multicolumn{1}{c|}{ 項 } & \multicolumn{1}{c}{ 設定条件 } \\
\hline 撮影距離 $($ 本体〜底質表層) & $33 \mathrm{~cm}$ \\
\hline 画像サイズ & $3264 \times 2448$ pixels \\
\hline 撮影モード & フラッシュ撮影 \\
\hline
\end{tabular}

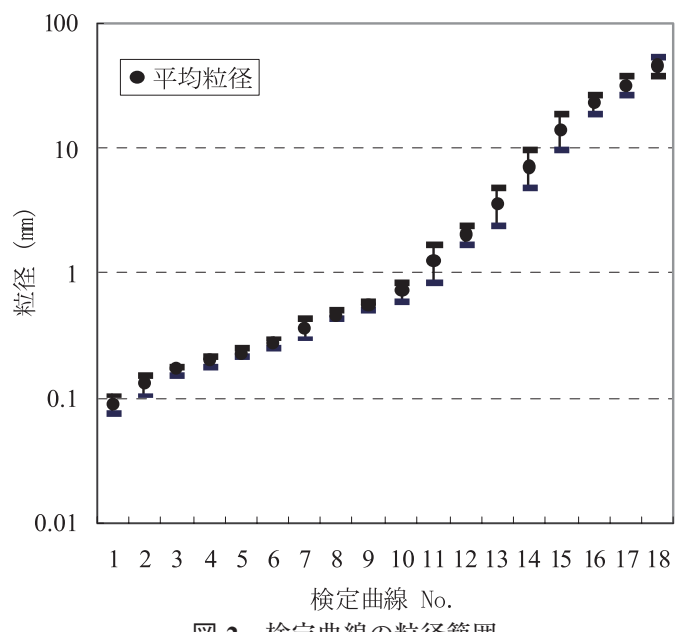

図-2 検定曲線の粒径範囲

のデジタルカメラでも高画質の画像が得られるようにな り，これを利用した底質粒径の計測手法が提案されて いる.

たとえば，Rubin（2004）は，画像の空間的統計特性 を考慮して, 平均粒径を算出する手法を提案している. また, 辻本ら (2008) は, 撮影点の斜面勾配や撮影距離, 底質の湿潤状況の違いによる解析結果から本計測方法の 妥当性について検証するとともに, 室内実験及び現地海 岸での適用を試みている.

本手法ではまず，あらかじめ粒径のわかっている単一 粒径からなる検定曲線用の底質サンプルを複数用意す る. 本研究では, 図-2に示すとおり現地で採取した底質 （粒径 $0.075 〜 53 \mathrm{~mm}$ ）を18階級にふるいわけ，これを底 質サンプルとした，次に，各サンプルを表-1に示す条件 で，デジタルカメラ（COOLPIX P6000, Nikon社）を用 いて撮影し，得られた各画像をもとに，基準となる矩形 領域の輝度值と, その矩形領域から距離 だけ離れた同サ イズの矩形領域の輝度值との空間的自己相関係数を式 （1）で算出した後, 粒径別の検定曲線を作成した.

$$
r=\frac{\sum_{i}\left(x_{i}-\bar{x}\right)\left(y_{i}-\bar{y}\right)}{\sqrt{\sum_{i}\left(x_{i}-\bar{x}\right)^{2}} \sqrt{\sum_{i}\left(y_{i}-\bar{y}\right)^{2}}}
$$

ここに, $x_{i}, y_{i}$; 矩形領域内の画素 $i$ での輝度值, $\bar{x}, \bar{y}$ : 矩 形領域内の平均輝度值である.
画像 A
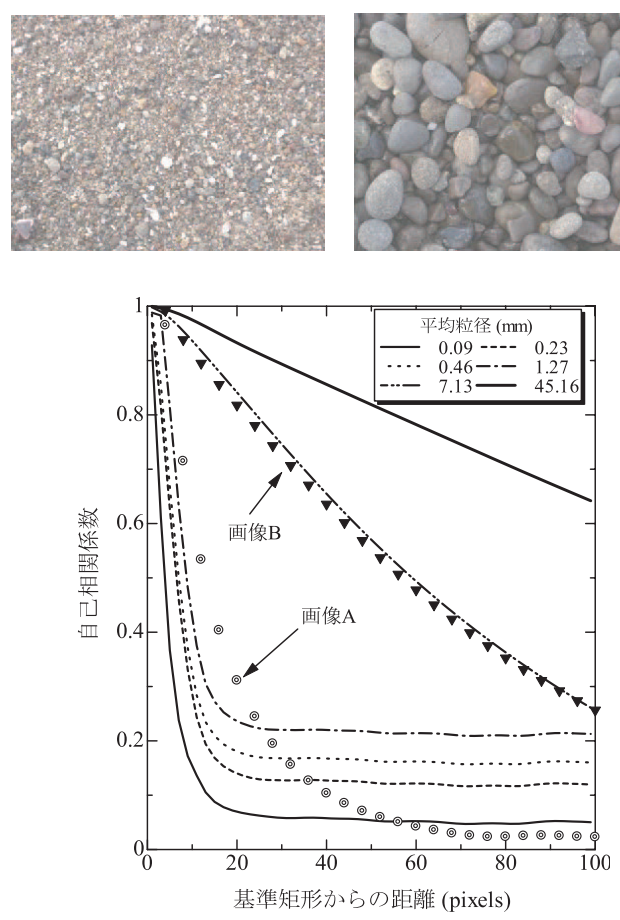

図-3 粒径別検定曲線と解析值の分布

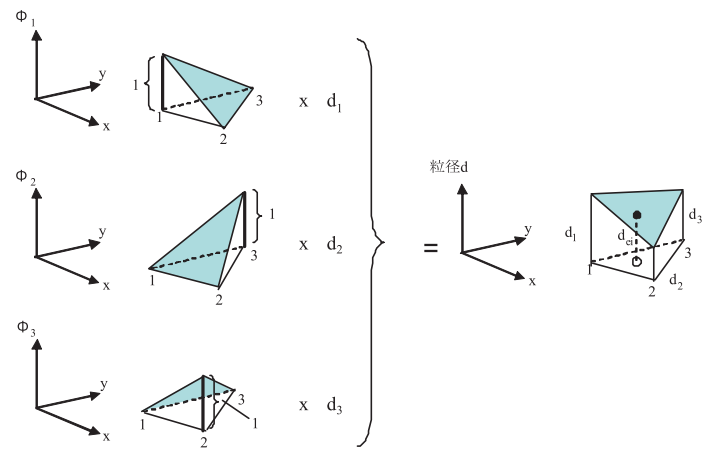

図-4 2 次元 1 次補間関数と内挿法

図-3に粒径ごとに求めた画像間距離と自己相関係数と の関係（一部抜粋）を示す. 各粒径とも基準区間からの 距離が離れるにつれて自己相関係数が減少していくこと がわかる．粒径が細かいほど，隣接する別の砂粒子との 距離が近くなるため, 矩形領域間の距離がわずかでも離 れると, 自己相関係数が大きく減少する。なお，これら の検定曲線は, サイズの異なる単一粒径から得られたも のであるため, 検定曲線どうしが交差することはない.

本図には同じ表-1の条件で撮影された現地海岸の底質 画像をもとに得られた画像間距離と自己相関係数との関 係についても示している。現地調査で得られた画像 $\mathrm{A}$, B はいずれも混合粒径であるが, 検定曲線 (単一粒径) 


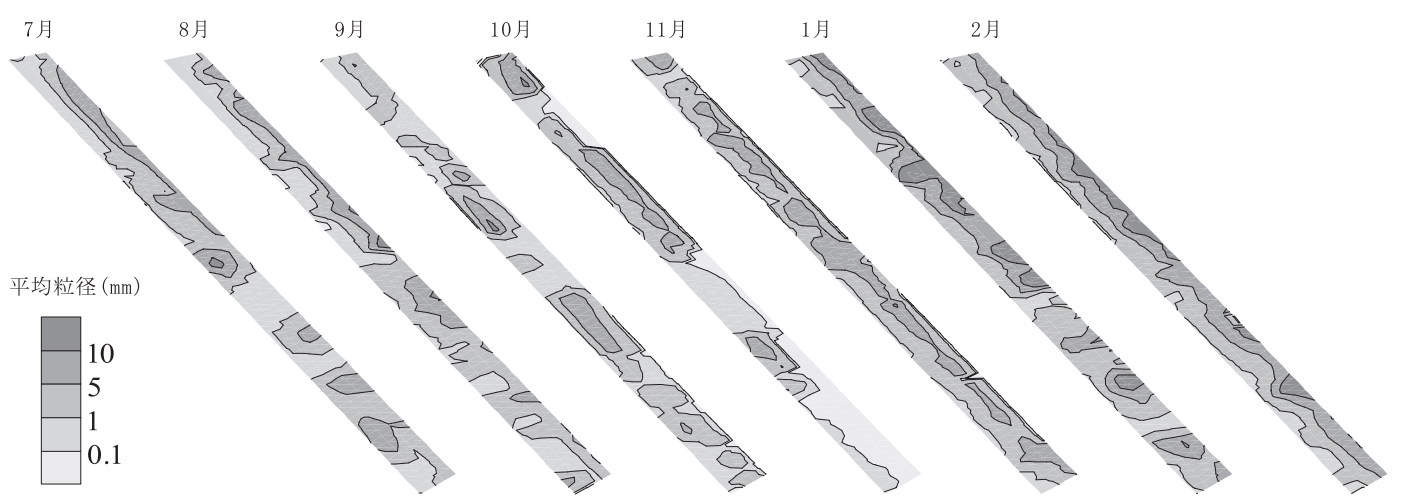

図-5 平均粒径の推移（304点での定点モニタリング）

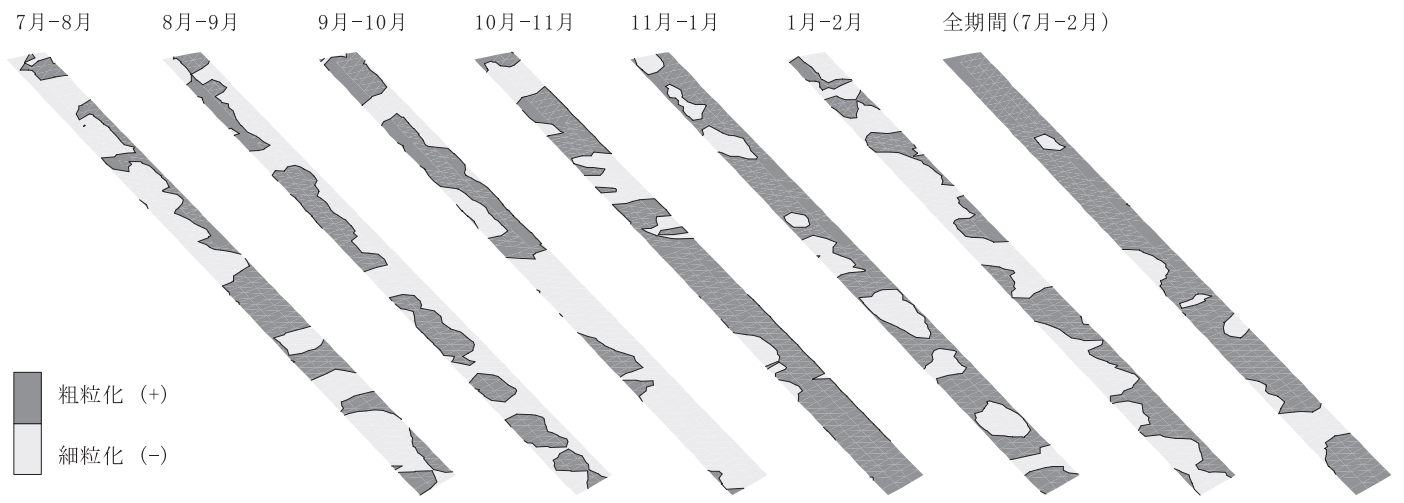

図-6 底質の粗粒化, 細粒化

の場合と同じく，基準区間からの距離が離れるにつれて 自己相関係数が減少する傾向がみられる。ただし，混合

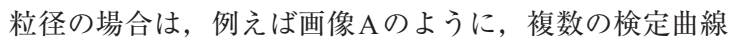
と交差することがある。このような混合粒径に対しては, 複数の粒径が線形的に輝度分布に影響しているものと し, 式（2）で示される線型方程式を解くことにより, 平均粒径を算出した。

$$
\begin{gathered}
x_{(1,1)} x_{1}+a_{(1,2)} x_{2}+\cdots+a_{(1, m)} x_{m}=b_{1} \\
\imath_{(2,1)} x_{1}+a_{(2,2)} x_{2}+\cdots+a_{(2, m)} x_{m}=b_{2} \\
\vdots \\
\imath_{(n, 1)} x_{1}+a_{(n, 2)} x_{2}+\cdots+a_{(n, m)} x_{m}=b_{n}
\end{gathered}
$$

ここに, $a_{(k, j)}$ : 画素間距離 $k, j$ 番目の粒径の空間的自己 相関係数 (検定曲線), $x_{j}: j$ 番目の粒径が含まれる割合, $b_{k}$ : 画素間距離 $k$ における自己相関係数（サンプル画像） である.なお, 式 (2) では, $x_{j}$ のみが未知数となり, 非 負条件を有する最小二乗法（Lawson・Hawson，1974） により決定することができる。

\section{3. 淡路島・成ヶ島東岸砂浜における底質の時空 間変動}

\section{(1) 現地調査結果}

2009年7月から 2010 年 2 月にかけて毎月 1 回（ただし， 2009 年 12 月は器材不良により欠測), 淡路島・成ヶ島東 岸砂浜（岸沖方向 $30 \mathrm{~m}$, 沿岸方向 $750 \mathrm{~m}$ ) において, 沿岸 方向に 4 本の line (Line-1：汀線直上〜 Line-4：後浜の海 浜植生生育境界付近）を設け, 各Line上, 約 $10 \mathrm{~m}$ ごとに 前章と同一条件で表層底質の画像撮影を行った。これら の画像をもとに前章の Rubin（2004）が提案する画像の 空間統計特性を考慮した手法によって, 各画像の平均粒 径を算出した。

各撮影点には歩測により移動し，携带型 GPS (MobileMapper ${ }^{\mathrm{TM}} 6$, MAGELLAN 社) を用いて位置情報を 記録した。この段階では, 厳密な意味での定点計測とは ならない。そこで，デローニによる要素分割法（谷口， 1992）を利用して, 各撮影点を節点とする三角形要素分 割を行い，平均粒径の空間分布図を作成したのち，これ をもとに図-4に示す 2 次元 1 次補間関数 $\phi_{i}$ を用いて, あら かじめ用意した定点格子上の平均粒径を空間補間によっ て算出した。すなわち, 定点格子上の平均粒径は, その 


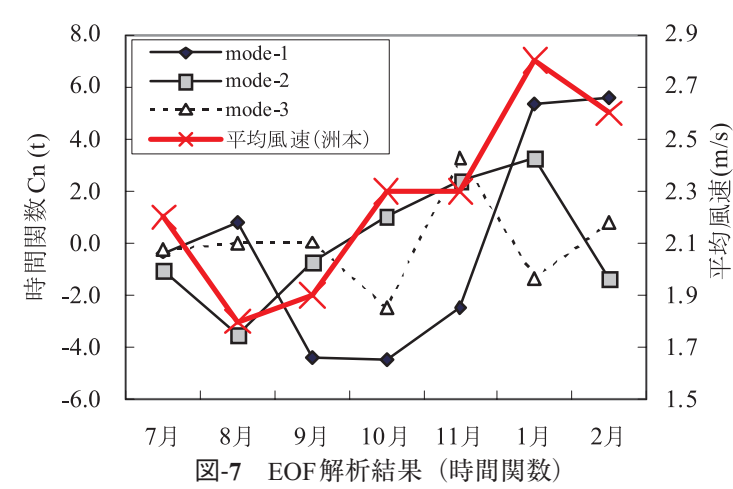

点が含まれる三角形要素の各節点の平均粒径の值を用い て，次式で評価される.

$$
\begin{aligned}
& \phi_{i}=\frac{1}{2 \Delta^{e}}\left(a_{i}+b_{i} x+c_{i} y\right) \quad(i=1,2,3) \\
& d_{50}(x, y)=\sum_{i=1}^{3} \phi_{i}(x, y) d_{i}
\end{aligned}
$$

ここに, $\Delta^{e}$ : 三角形要素 $e$ の面積, $d_{i}$ : 節点 $i$ の粒径（解 析值), $a_{i}, b_{i}, c_{i}$ は節点の $x y$ 座標を用いて計算される係数 である。このようにして, 各line上 76 点, 合計 304 地点 の平均粒径を算出し, その空間分布を把握した.

図-5に平均粒径の空間分布の推移を示す。汀線付近で は, 夏季から秋季にかけて, 底質が一度細粒化した後, 冬季にかけて粗粒化に転じる傾向がみられる。一方, 海 浜植生の繁茂する後浜付近の底質については, 植生の繁 茂する夏季には粒径 $1 \mathrm{~mm}$ 程度の細砂が捕捉される傾向が 強いが，冬季になるにつれてこれらの植生が枯死するた め, 捕捉効果が低下し, 同様に粗粒化する傾向にあるこ とがわかる。

図-6は図-5に示す前後の調查結果から底質粒径の変化 量をみたものである. 調查開始時（2009年7月）と調查 終了時（2010年2月）という約半年の時間スケールでは, 本砂浜は全体的に粗粒化する傾向にあると判断される が，1〜2ケ月という時間スケールでの比較からは，局所 的な粗粒化, 細粒化を繰り返していることがわかる.

\section{（2）経験的固有関数法による底質変動要因の抽出}

成ヶ島東岸砂浜の底質変動要因について考察するた め, 経験的固有関数法（以下, EOF解析）による時間関 数と空間関数の抽出を試みた.

ここでは, 観測日ごとに各ラインの平均粒径の平均值 を算出する. 次に, ある観測日 $t$ のラインににおける平均 粒径の平均值を $d_{50}(l, t)$, 全期間平均の平均粒径を $\overline{d_{50}}(l)$ として, 全期間平均值からの変動量

$$
\Delta d_{50}(l, t)=d_{50}(l, t)-\overline{d_{50}}(l) \cdot
$$

を求める.これを時間方向の固有関数 $c_{i}(t)$ と空間方向

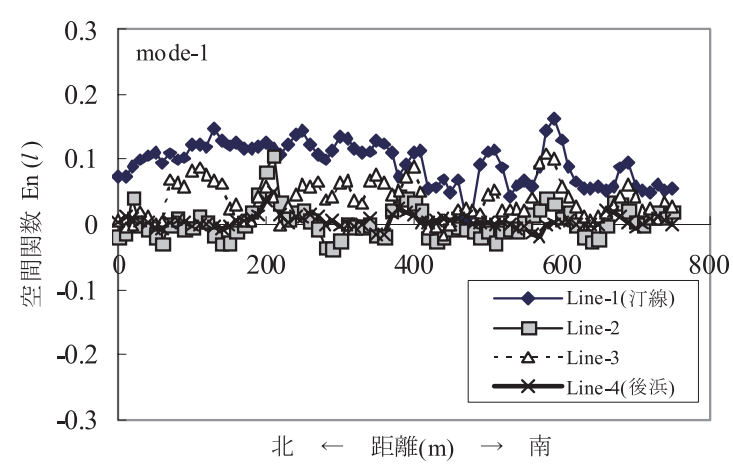

図-8 EOF解析結果 (空間関数)

の固有関数 $e_{i}(l)$ を用いて

$$
\Delta d_{50}(l, t)=\sum_{i=1}^{n} c_{i}(t) e_{i}(l)
$$

と表現し，Winantら（1975）の方法によって $c_{i}(t)$ と $e_{i}(l)$ を求めた。ここで $e_{i}(l)$ は対象とするライン固有 のものであり, デー夕から経験的に得られるものである. $c_{i}(t)$ と $e_{i}(l)$ は寄与率の大きい順に第 1 次モード $c_{1}, e_{1}$, 第2次モード $c_{2}, e_{2} \cdots$ とする.

図-7にEOF解析により得られた時間固有関数を示す. 最も寄与率の高い mode-1（寄与率 $54 \% ） の$ 時間関数は, 現地付近で観測された平均風速の推移と似た傾向を示し ており，現地底質の時間変動には風の影響が卓越してい るのではないかと考えられる.

図-8にEOF解析により得られた空間固有関数 (mode-1) を示す. 汀線直上（Line-1）では，他のラインと比較し て值が大きく，この付近での変動が最も大きいことがわ かる. また, 沿岸方向の変化量の違いについてみると北 岸側での変化量が南岸側でのそれと比較して大きくなっ ており, 湾曲した海岸形状により潮汐や波浪の侵入の程 度が異なることを示すものと考えられる。一方, 後浜 (Line-4) での変化は汀線付近と比較して小さくなってお $り$, 海浜植生による砂の捕捉効果が示唆された.

\section{4. 成ヶ島における風の出現特性とそれを考慮し た飛砂量算定}

前章(2)の統計解析の結果から, 淡路島・成ヶ島東岸 砂浜の底質変動要因として風が重要であることが示唆さ れた。 そのため, 飛砂による砂浜全体の底質異動量を把 握しておくことが重要であると考えられる。しかし, 現 地における風向風速の連続デー夕は取得されていない. そこで, 最寄の気象庁AMeDAS の観測デー夕（観測点： 洲本）で代替できるかどうか検討するため，2009年 8 月， 10 月, 2010 年 1 月に現地海岸において風向風速計 （KDEC21-KAZE，ノースワン社）を設置し，測定間隔 1 秒で地上 $100 \mathrm{~cm}$ の風向風速デー夕を取得したのち, 10 


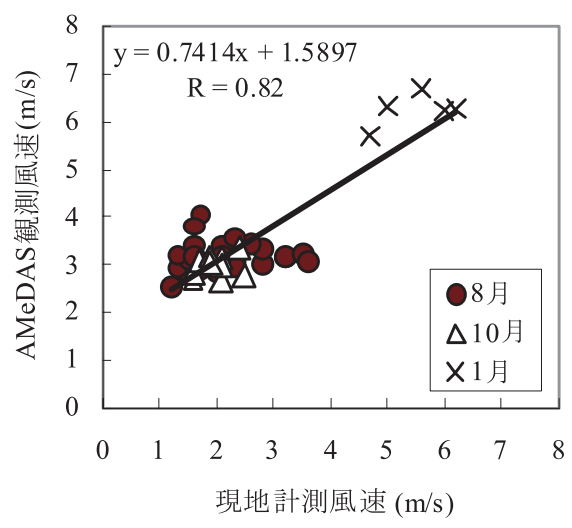

図-9 風速データの検証

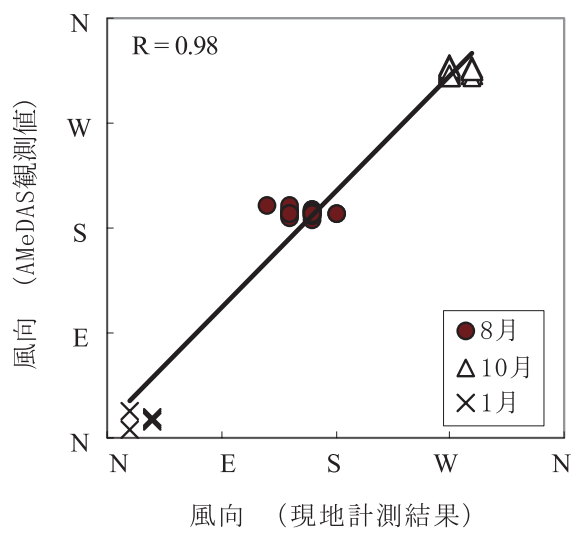

図-10 風向データの検証

分平均值を算出して, 気象庁 AMeDAS の観測データと比 較した。

図-9に風速デー夕，図-10に風向デー夕の検証結果を示 す. 風速についてみると, 夏季〜秋季にかけては観測值, 気象庁 $\mathrm{AMeDAS}$ デー夕ともに $4 \mathrm{~m} / \mathrm{s}$ 以下であるが，冬季 には季節風が発達するため, $5 \mathrm{~m} / \mathrm{s}$ 以上の強い風の出現が 見られる.いずれの時季とも観測值, 気象庁 AMeDAS デ 一夕には有意な相関がみられた。一方, 風向についても 季節ごとに卓越方向は異なるが, 有意な相関が見られた. 以上の結果から, 現地の飛砂量算定に必要な風向風速デ ー夕は気象庁AMeDAS の観測デー夕（10分平均值）で代 用可能であると判断した．そこで気象庁の 10 分平均風速 と最頻出風向を用いて, 淡路島・成ヶ島に扔ける飛砂量 の時間変化を算出した。飛砂量算定に必要な摩擦速度は, 河田（1950）の経験式を用いた。また，砂粒が運動を開 始する移動限界摩擦速度 $u_{*_{c}}$ は, Bagnold（1954）の式で 評価し, 全飛砂量 $Q$ は, 河村（1951）の式を適用するこ ととした.

図-11に飛砂量計算の結果を示す。本図より夏季には 沿岸方向（南－北）への飛砂が卓越する一方，冬季には 岸沖方向（西＼cjkstart東）への飛砂が卓越していることがわか

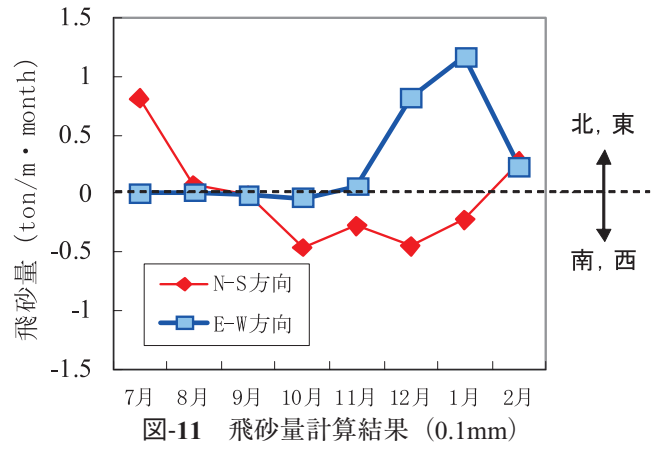

る. 図-5 の平均粒径の推移をみると, 夏季から秋季にか けて砂浜南端に堆積していた細砂が, 秋季から冬季には 一掃されており, 定性的には飛砂量計算の結果と一致す る結果が得られた。

\section{5. まとめ}

本研究の結果, 淡路島・成ケ島に打ける平均粒径の時 間変動は, 風の出現特性との相関が高く, 空間変動は岸 沖方向にほぼ一様で, 標高に応じた変動特性が見られる ことがわかった．今後は波浪による底質変化や地形変化 と底質粒径変化の応答性についても検討する予定であ る。な㧍, 本研究の一部は文部科学省研究費補助金基礎 研究 (C) 課題番号21560547の補助によるものである.

\section{参 考 文 献}

宇野宏司・近藤文音・辻本剛三・柿木哲哉 (2009)：淡路島 · 成ヶ島に押ける浮遊ごみの実態把握調查, 海洋開発論文 集, 25 卷, pp. 117-122.

河田三治（1950）：防災林に関する調查報告，治山事業参考資 料, 林野庁, pp.1-22.

河村龍馬 (1951)：飛砂の研究, 東京大学理工学研究所報告, 第5巻，第3-4号, pp.95-112.

谷口健男（1992）：FEMのための要素自動分割ーデローニ三角 分割法の利用 - , 森北出版, $198 \mathrm{p}$.

辻本剛三・山田文彦・柿木哲哉（2008）：砂画像粒子を用いた 底質粒径の計測法の妥当性に関する研究, 海洋開発論文 集, Vol. 24, pp. 1207-1212.

細田龍介（2007）：由良湾におけるアマモ復活の経緯とその検 証一自然と人間の共生の例 -, 海洋と生物, Vol. 30 , No.5, pp. 685-694.

吉田英治・荒木進歩・出口一郎・池田智大（2002）：混合砂啋 海岸に抢ける底質の分級と断面変形, 第4 4 回海講論文集, pp. 461-465.

Bagnold, R. A. (1954) : The Physics of Blown Sand and Desert Dunes, Methuen \& Co. Ltd., 265p.

Lawson, C.L. and Hawson, B.J. (1974) : Solving Least Squares Problems : Eglewood Cliffs, New Jersey, Prentice-Hall, 340p.

Rubin, D.M. (2004) :A simple autocorrelation algorithm for determining grain size from digital images of sediment, Journal of Sedimentary Reserch, Vol.74, No.1, pp.160-165.

Winant, D.C., D.L. Inman and C.E. Nordstrom. (1975) : Description of seasonal beach change using empirical eigenfunction, J.G..R., Vol.80, No.15, pp.1979-1986. 